\author{
○渡邊博志 ${ }^{11}$ 、棚瀬純男 ${ }^{2)}$ 、中城圭介 ${ }^{1)}$ 、岩尾康範 ${ }^{1)}$ 、御手洗万希 ${ }^{1)}$ 、 \\ 丸山 徹 ${ }^{1} 、$ Ulrich Kragh-Hansen ${ }^{3}$ 、小田切優樹 ${ }^{1)}$ \\ 1)熊本大·薬 $\cdot$ 薬剂学、2)熊本大 $\cdot$ 医 $\cdot$ 第二生化学、 \\ ${ }^{3}$ Dept. of Med. Biochemistry, Univ. of Aarhus

\section{TOPOLOGY ANALYSIS OF DRUG BINDING SITES ON HUMAN SERUM ALBUMIN USING SITE-DIRECTED MUTAGENESIS}

\author{
Hiroshi WATANABE ${ }^{1)}$, Sumio TANASE ${ }^{2)}$, Keisuke NAKAJOU ${ }^{1)}$, Yasunori IWAO $^{1)}$, \\ Maki MTARAI ${ }^{1)}$, Toru MARUYAMA ${ }^{1)}$, Ulrich KRAGH-HANSEN ${ }^{3)}$ and Masaki OTAGIRI ${ }^{1)}$ \\ ${ }^{1)}$ Dept. of Pharmaceutics, Fac. of Pharm. Sci, Kumamoto Univ. \\ ${ }^{2)}$ Dept. of Biochemistry, School of Medicine, Kumamoto Univ. \\ ${ }^{3}$ Dept. of Med. Biochemistry, Univ. of Aarhus
}

【目的】ヒト血清アルブミン(HSA)分子上には大き く分けてサイト Iとサイトாの二つのリガンド結合 サイトが存在する。なかでもサイト I は、種々の 構造の異なる薬物分子を受け入れる構造適応性 (configurational adaptability)を有して抢り、複数の开 ブサイト (Ia, Ib，Ic) から形成されることが明らかと されてきた。また、サイト片結合するリガンドは 一般に疎水性構造から離れた位置にカルボン酸等 の負の電荷が局在する構造を有して扔り、その結 合領域は比較的rigidである。さらに、このサイトII はHSAが有するエステラーゼ様活性の活性部位で あることが示唆されている。

ところで、HSA は $\mathrm{pH} 6 \sim 9$ で構造変化 (Neutral (N)-Base (B) 転移) を惹起し、この N-B 転移に伴い 薬物結合性が変化し、特にサイトI結合型薬物は B 型に扔いてその結合性が増大する1)。

このような背景の下、上述したリガンド結合サ イトのトポロジー解析を目的として、化学修飾並 びにX線結晶構造解析等のデー夕から変異の標的ア ミノ酸としてサイトIとサイトIIに位置する ${ }^{199} \mathrm{Lys}$, ${ }^{214} \mathrm{Trp},{ }^{218} \mathrm{Arg},{ }^{242} \mathrm{His}$ 及び゙10 $\mathrm{Arg},{ }^{411} \mathrm{Tyr}$ を選択した。

Pichi酵母を宿主として変異型HSA(K199A, W214A, R214H, H242Q, R410A, Y411A, Y411S, Y411F, R410A/Y411A)を作製し、HSAの機能に抢けるそれ らアミノ酸残基の役割について考察した。

【実験方法】变異体はPichia pastorisを宿主とした 発現系により作製した。結合実験には代表的サイ トリガンドとしてワルファリンを用いた。またサ イトIIリガンドとしてはケトプロフェンとジアせ パムを用いた。エステラーゼ様活性については酢 酸p-ニトロフェニルを基質とした。加水分解後に生 成する $p$-ニトロフェノールの増加で測定し、擬一次
速度定数として見かけの加水分解速度定数を算出 することにより検討を行った。

【結果と考察】サイトIに位置する ${ }^{410} \mathrm{Arg} と^{411} \mathrm{Tyr}$ の 機能検索：サイトI表面に位置する ${ }^{410} \mathrm{Arg} と^{411} \mathrm{Tyr}$ の 側鎖がリガンドとの結合過程にどの程度関与して いるかを検討するため、限外濾過法により解析し た。矢の結果ケトプロフェンの場合、その結合過 程にはケトプロフェンのカルボン酸と ${ }^{410} \mathrm{Arg}$ との静 電的相互作用に加え、ケトン基と年 ${ }^{41} \mathrm{Tyr}$ の水酸基と の水素結合及び芳香環同士の特異的相互作用が重 要であることが推察された。また、ジアぜパムの 結合過程には、ケトン基と ${ }^{411} \mathrm{Tyr}$ の水酸基との水素 結合及び芳香環同士の特異的相互作用が大変重要 であるものの、 ${ }^{410} \mathrm{Arg}$ はその結合には関与してない ことが示唆された。

エステラーゼ様活性について検討した結果、 ${ }^{411} \mathrm{Ty}$ ○変異により活性が完全に消失したことから、 その活性中心は ${ }^{411} \mathrm{Tyr}$ の水酸基であると推察された。 また ${ }^{410} \mathrm{Arg}$ の変異により大きく活性の減少が認めら れたことから、その反応性には ${ }^{410} \mathrm{Arg}$ のグアニジ， 側鎖が大きく関与していることが確認された2)。 サイトIのトポロジ一解析：近年 Familial disalbuminemic hyperthyroxinemia患者の血中チロキ シン濃度の増大が、HSAの変異(R218H, R218P)に よるチロキシンの HSAへの親和性の増大に起因す ることが確認された。また、この患者のHSAとワ ルファリンとの結合親和性は約5倍低下しているこ とが報告されている。そこでX線結晶構造解析デー 夕を基に、サイト結合ポケットに側鎖を伸ばして いるアミノ酸残基を選び、K199A, W214A, R218H 及びH242Q変異体を作製し以下の検討を行った (Table 1)。その結果、 pH7.4でのワルファリンの結 
合性は K199A, H242Qにおいて各々4及び6倍増大し、 W214A, R218Hでは各々2及び3倍結合定数の減少が 観察された。従って、 ${ }^{214} \mathrm{Trp},{ }^{218} \operatorname{Arg}$ の側鎖はワルファ リンの結合にとって positiveに㗢いており、逆に ${ }^{199}$ Lys, ${ }^{242}$ Hisの側鎖はその結合において negativeに機 能していることが明らかとなった。しかしながら、 今回の結果ではワルファリンの結合親和性を大き く低下させるようなアミノ酸変異を見い出すこと はできなかった。

上述したように、HSAのpH依存コンフォメーショ ン変化、N-B転移に伴いサイトIリガンドの結合性 は顕著に変化することから、その結合サイトの構 造はflexibleであると考えられる。そこで、サイトI リガンド、ワルファリンの結合性に及ぼす $\mathrm{pH}$ の影 響について検討した結果、W214A及びR218Hでは $\mathrm{pH}$ 上昇に伴う結合性増大の程度は他の変異体に比 べ小さかった(Table 1)。一方、K199A及びH242Qは 野生型に比べてN-B転移の影響をより受け易くなる ことが明らかとなった。X線結晶構造解析によると、 ${ }^{214} \mathrm{Trp}$ と ${ }^{218} \mathrm{Arg}$ 及び ${ }^{199} \mathrm{Lys}$ と ${ }^{242} \mathrm{His}$ は各々 $3 \sim 4 \AA$ の距離 にあり非常に近くに位置することが分かっている。 ワルファリン結合領域のトポロジーについて考察 すると、本来、ワルファリンの結合にとって妨げ
となっている ${ }^{199} \mathrm{Lys}{ }^{242} \mathrm{His}$ 近傍のポケットの広がり (摇らぎ)が、B型に扮けるワルファリンの結合親和 性の増大の原因となっている可能性が示唆された。 加えて、 ${ }^{214} \mathrm{Trp} \mathrm{P}^{218} \mathrm{Arg}$ 近傍にはN-B転移によるサイ トIのミクロ環境変化を引き起こす引き金となるよ うなアミノ酸残基の存在が推察された。

以上のように、部位特異的変異法を用いて、 HSA分子上の今回ターゲットとして選択した全て のアミノ酸残基がリガンドとの結合過程や、エス テラーゼ様作用に大きく寄与していることが明ら かとなった。

Table 1 Binding of warfarin to wild-type or mutant rHSA at $25^{\circ} \mathrm{C}$

\begin{tabular}{cccc}
\hline & \multicolumn{3}{c}{ association constant $\left(\times 10^{5} \mathrm{M}^{-1}\right)$} \\
\cline { 2 - 4 } & $\mathrm{pH} 6.5$ & $\mathrm{pH} 7.4$ & $\mathrm{pH} 8.2$ \\
\hline Wild-type & $2.08 \pm 0.16$ & $3.63 \pm 0.22$ & $10.56 \pm 0.15$ \\
K199A & $3.70 \pm 0.10$ & $15.90 \pm 0.75$ & $31.06 \pm 1.02$ \\
W214A & $1.47 \pm 0.23$ & $1.71 \pm 0.13$ & $4.18 \pm 0.95$ \\
R218H & $0.80 \pm 0.11$ & $1.13 \pm 0.23$ & $3.49 \pm 0.16$ \\
H242Q & $5.22 \pm 0.31$ & $22.17 \pm 0.86$ & $35.96 \pm 1.26$ \\
\hline
\end{tabular}

\section{【Abstract】}

Recombinant wild-type and mutant human serum albumins were produced using a yeast expression system. We investigated, by ultrafiltration, the high affinity binding of two representative site II-ligands, namely ketoprofen (KP) and diazepam (DZ). According to the crystal structure of HSA, the residues of ${ }^{410} \mathrm{Arg}$ and ${ }^{411} \mathrm{Tyr}$ protrude into the center of site II (in subdomain $3 \mathrm{~A}$ ), and the binding results showed that the guanidino moiety of ${ }^{410} \mathrm{Arg}$, the phenolic oxygen and the aromatic ring of ${ }^{411} \mathrm{Tyr}$ are important for KP binding. The guanidino moiety probably interacts electrostatically with the carboxyl group of KP, the phenolic oxygen could make a hydrogen-bond to the ketogroup of the ligand, and the aromatic ring may participate in a specific stacking interaction with one of or both of the aromatic rings of KP. By contrast, ${ }^{410} \mathrm{Arg}$ is not important for DZ binding. In addition to its unique ligand binding properties, HSA also possesses an esterase-like activity, and studies with p-nitrophenyl acetate as a substrate showed that although ${ }^{410} \mathrm{Arg}$ is important, the enzymatic activity of albumin is much more dependent on the presence of ${ }^{411} \mathrm{Tyr}$. In order to characterize the warfarin (WF) binding site, ${ }^{199} \mathrm{Lys},{ }^{214} \mathrm{Trp},{ }^{218} \mathrm{Arg}$ and ${ }^{242} \mathrm{His}$ were mutated. At pH 7.4, the affinity of H242Q and K199A were found to be about 6 and 4 times higher as compared to that of wild-type HSA, respectively. However, the affinity of R218H and W214A for WF were about 3 and 2 times reduced. These results show that the side chain of ${ }^{214} \operatorname{Trp}$ and ${ }^{218} \mathrm{Arg}$ are important for WF binding. In contrast, the side chains of ${ }^{199} \mathrm{Lys}$ and ${ }^{242} \mathrm{His}$ interfere with binding. Finally, the effect of the N-B transition on WF binding will be discussed.

\section{【References】}

1) Peters, T. Jr. All About Albumin: Biochemistry, Genetics, and Medical Applications, Academic Press, San Diego, California, 1996. 2) H. Watanabe et al. Biochem. J., 349, 813-819 (2000). 